Saudi Journal of Humanities and Social Sciences

Abbreviated Key Title: Saudi J Humanities Soc Sci

ISSN 2415-6256 (Print) | ISSN 2415-6248 (Online)

Scholars Middle East Publishers, Dubai, United Arab Emirates

Journal homepage: http://scholarsmepub.com/shihs/

Original Research Article

\title{
The Role of the Teacher in the Kazakh Rural School
}

\author{
Dzhusupov U. $\mathrm{S}^{1}$, Konarbayev Z. $\mathrm{H}^{2}$, Issayeva A. $\mathrm{U}^{3 *}$, Zhumadullayeva A. $\mathrm{I}^{2}$, Balgabekova A ${ }^{2}$, Ashirbayeva S. B ${ }^{2}$ \\ ${ }^{1}$ Rural School №6, Khantagy Village, Kazakhstan \\ ${ }^{2}$ Shymkent University, Zhybek Zholy St 131, Shymkent 160031, Kazakhstan \\ ${ }^{3}$ Professor, Shymkent University, Zhybek Zholy St 131, Shymkent 160031, Kazakhstan
}

DOI: $\underline{10.36348 / \mathrm{sjhss} .2019 . \mathrm{v} 04 \mathrm{i} 11.005}$

| Received: 13.11.2019 | Accepted: 20.11.2019 | Published: 28.11.2019

*Corresponding author: Akmaral Issayeva

\section{Abstract}

The peculiarity of Kazakh education is manifested in respect for the older generation. Elders of the family-elders pass on their experience and national traditions to the younger generation. But in the modern world with strict requirements to the competitiveness of young professionals, the life experience of elders is not enough. In such a situation, an important role is given to the school teacher as a source of new knowledge and a guide to new areas of knowledge. In this regard, the purpose of this study was to study the role of teachers in one of the rural schools in the South of Kazakhstan. It is shown that the peculiarity of the traditional Kazakh way of life, preserved in rural areas, allows to attract the local population to the educational process by organizing optional activities and intra-school organizations of interest.

Keywords: Rural Kazakh school, education of schoolchildren, ethnopedagogy, national traditions, family dynasties.

Copyright @ 2019: This is an open-access article distributed under the terms of the Creative Commons Attribution license which permits unrestricted use, distribution, and reproduction in any medium for non-commercial use (NonCommercial, or CC-BY-NC) provided the original author and source are credited.

\section{INTRODUCTION}

The profession of a teacher is one of the most important in the modern world. It is from the teacher, his personality, depends on the upbringing and education of children, and therefore the future of the whole country. It is not surprising that at all times outstanding figures of education highly appreciated the role of the teacher in the life of society. Currently, the teacher must have deep knowledge in the field of psychology of education, upbringing and formation of the personality of each child, be able to organize communication in educational activities, possess special knowledge and skills for the introduction of innovative innovations in school practice.

The leading component in the education of schoolchildren is the pedagogical goal. The purpose determines the content of the educational process, its methods, means, results. The teacher must always have a goal in every action, a good idea of the result of his work and create all the conditions for achieving this result. No system of educational means can be recommended as permanent, because the child himself changes, entering into new stages of personal development, the conditions of his life and activities change, the state changes, its requirements for the younger generation. Therefore, the system of pedagogical means should be set by the teacher so as to ensure its creative development and timely eliminate outdated methods, goals, requirements [1]. Accordingly, educational goals cannot be unchanged. This is another function of the teacher -the development of new educational goals and methods to achieve them, corresponding to the modern requirements of society. The teacher should, taking into account the peculiarities of the situation and the personal qualities of the student, each time find his educational method applicable to a particular student. In addition, it is necessary to maintain the principle of complexity in education, that is, it can not first conduct labor education, then aesthetic, then moral, ideological and political, and so on. Everything must go in unity. Most teachers of the Soviet school were focused on teaching children the basics of scientific knowledge using the reproductive method, which was based on the reproduction of the text of the textbook. Today we live in an environment where society imposes new requirements to the professional competence of the teacher.

The teacher of a modern school carries out various functions:

- Is a source of knowledge for students both during lessons, additional classes and consultations, and outside the educational process;

- Protects the life and health of children;

- Performs the management function that organizes the educational activities of students. 
The teacher must choose a method of teaching that organizes the educational activities of students, a method that creates conditions for achieving modern educational results, that is, focused on the formation and development of universal educational actions, a method that ensures the implementation of educational activities by the teacher in relation to himself;

- Creates pedagogical conditions for successful education, development and upbringing of children (function " education and upbringing»);

- Carries out pedagogical education of parents, regulation and coordination of educational influences of a family and school (function " interaction with parents»);

- $\quad$ Serves as a class teacher.

In connection with the variety of functions of the teacher, the requirements that society imposes on his personality become clear. One of the important components of the teacher's work is pedagogical communication, creating an atmosphere of psychological development of the student's personality. A teacher who knows how to create a calm working environment, an atmosphere of respect, activity of the child is preferable to a teacher whose students know all the rules, laws, but whose students are overloaded, constrained, have low self-esteem [2]. In this sense, pedagogical communication is more important than pedagogical technology.

Conditions of the effectiveness of the teacher are: professional competence, scientific-theoretical and methodological preparation, ability to identify causes of student difficulties and provide him with the necessary information to guide the discussion on the analysis and search for new to predict the actions of the student and his development in General, linked to control diagnostic actions analysis of the trajectory of development of the student and goals of working with it to plan its activities and to teach the planning of a student, to find and appreciate the positive in the child, even in the wrong actions [3]. Speaking of competence, we can also say about the broad erudition in the field of the taught subject, which goes beyond the school curriculum. This allows them to be interesting to the student in the part of communication with him, which lies in the interests of the student. It is very important to possess information technologies and use them in teaching practice [4]. They are able to answer questions and give the student a lot of additional information. But the scope of their competence does not go beyond awareness in this subject area of knowledge and does not apply to the issues of individual characteristics of students, methods of their diagnosis, variable work with them.

Confident possession of ways of implementation of feedback with the student should provide stimulation of the child's activities, providing timely and adequate assistance to students, instilling confidence and self-esteem. The activities organized by him should be diverse and combine a wide range of forms, methods, techniques and ways of activity of the teacher and student. He must be fluent in analytical, diagnostic and design skills, properly use the educational situation in achieving the development goals of the student. Its tasks include regulating and correcting the activities and development of the child, assessing and encouraging, modeling developmental situations and mobilizing the energy resources of students. The competence of the teacher includes the implementation of training and education of students, the use of modern educational technologies of training, including information and communication, the ability to effectively apply educational and methodological, information and other resources, constantly develop professionally and intellectually.

The professional qualities of a teacher are based on the following skills: to modify the curriculum, to work according to the curriculum, to advise students, to assist in the independent acquisition of knowledge. It is necessary to respect the child's desire to work independently, the ability to refrain from interfering with the creative process of the child, to encourage work on projects proposed by students, to derive maximum benefit from Hobbies, specific Hobbies and inclinations of students.

The peculiarity of Eastern, including Kazakh education is respect and reverence for the older generation. Wisdom and knowledge passed on to the younger generation are usually based on many years of experience in the relationship between aksakals (literally: ak-white, sakal-beard, elders) and the world around them. But in a rapidly developing time with stringent requirements for the formation of competitive young professionals, the usual worldly wisdom of elders is not enough. In such a situation, an important role is given to the school teacher as a source of new knowledge and a guide to new areas of knowledge.

In this regard, the purpose of this study was to study the role of teachers in one of the rural schools in the South of Kazakhstan.

\section{OBJECT AND METHODS OF RESEARCH}

The object of the study is the author's rural school No. 6, located in the village of Khantagi, near Kentau city in the South of Kazakhstan.

The study used such methods as problem situation; retrospective method; musical generalization; pedagogical experiment, consisting of preparatory, ascertaining, search-forming and control stages, including pedagogical observation, conversations, initial, current and final measurements, fixation of the degree of assimilation of musical material, its 
compliance with the age characteristics of children's perception. Besides such pedagogical methods as methods of verbal influence were used: didactic story, description, explanation, conversation, analysis, lecture, instruction, comments and remarks, orders, commands and instructions; methods of visual influence or providing visibility: direct visibility, indirect visibility, urgent information.

In the education of students in the Kazakh rural school used the techniques of ethnopedagogy as instruction and edification, personal example of elders, imitation.

\section{RESEARCH RESULTS AND DISCUSSION}

In folk pedagogy, the active center of education is the family, it focuses the main wealth of content, methods and forms of the national system of education. Communication with adults is of great importance for ethno-pedagogical support of selforganization of the personality, this natural process in which the child learns the norms and morals of society, is enriched by the experience of life [5]. The peculiarity of Eastern, including Kazakh education is respect and reverence for the older generation. The system of national education is the basis of ethno-pedagogical science. Rural life, working way of life have always been the basis of public morality. After all, the village has preserved folk traditions (labor, family, holiday), community, education of children "all over the world".

The main task of the rural national school: education of ethno-culturally oriented personality with a formed national consciousness, a developed system of universal values, i.e. a person who understands the role of his nation, ethnic group in the world historical process. Ethnopedagogization of educational process in rural school, unification of rural society is not only pedagogical, but also actual social problem. To promote the development of positive trends in the revival, preservation and development of folk cultures is a new social and pedagogical function of the school and the system of education of children and youth in General. Ethnopedagogization involves the construction of an educational system based on folk traditions as the most important means of transmitting to children the historical experience of the people in the form of various social and moral norms and rules.

The author's school No 6 became a pilot site for the development and implementation of innovative ideas training and education of schoolchildren, in which an important role was played by the teacher of Russian language A. S. Sariev and mathematics teacher M. Medeubaev. Speaking about the role of the teacher in the education of schoolchildren, I would like to focus on a number of specialists who have organized their areas in rural schools. These are choirmaster Meiramkul Dairabayeva and concertmaster Aralbay Baizhanov, who organized a three-voice choir of school teachers, who repeatedly performed at different music competitions. On an initiative basis, A. Baizhanov opened a school circle "Elim-AI" (translated from Kazakh: my Country) and an optional author's course for high school students "History of musical culture of Kazakhstan". In order to popularize his developments, A. Baizhanov held several open lessons and seminars for colleagues from a number of regions of Kazakhstan, where information about the legendary Kazakh composers, the importance of Kazakh ornaments on musical instruments, etc. was presented in an accessible and fascinating form. One of the successors of the teacher Baltaev Nurgaliya Gubaidullauly describes his music teacher as follows:"...when Aralbay Baizhanov led a lecture about the composer Kurmangazy, he fully entered into his role, and virtuoso dombra playing created in our imagination pictures of the great steppe with the smell of wormwood and the trampling of herds of horses...". Baltaev N. chose the profession of a music teacher and after working for several years in the author's school, currently heads the city music school in Kentau. These examples are not the only ones in the author's school. One can note the role of such teachers as A. Konysbekov, who organized a consolidated orchestra of folk instruments of teachers and students; K. Umirbayev, teaching the basics of the terme (translated from Kazakh: "narration", a special kind of musical instrumental work); B. Orynbasarov-organizer and head of the school orchestra of wind instruments.

The modern pedagogical situation is characterized by diversity and dynamism, and the teacher must skillfully adapt to the constantly occurring changes in the content of training. A special role in the process of professional self-development of the teacher is played by his willingness to new, advanced. The main components of the teacher's readiness: psychological aspect, deep knowledge of the subject, the ability to implement the knowledge gained.

The teacher should be manifested in the following interrelated characteristics: General erudition, including a deep knowledge of the psychological, physiological, age characteristics of children, as well as ways and conditions of their development; the qualities of the teacher's personality, the style of his pedagogical activity and the nature of his communication with the student and others, his values. Such teacher possesses that component of pedagogical skill which allows it to transfer successfully to the pupil necessary, even expanded volume of subject knowledge, to train it in subject actions and application of the received knowledge in a typical situation.

The teacher should be ready to competently plan work with students with an attitude to increase interest, use an individual approach taking into account the results of diagnosis, create the necessary conditions for the intellectual development of the child. In his interaction with the student should be rationally 
combined elements of explanation and practical work, theoretical training and teaching rational methods of educational and creative activity. Any teacher not only teaches his subject, but also carries out pedagogical activities in General. This means that as a teacher he is constantly in interaction with children, parents, colleagues, other people. Of particular value is the involvement of the family component in the educational process. In this regard, the role of family musical ensembles Baltaev, Akhmetov, Kalabaev, which include representatives of several generations, in the education of schoolchildren is undoubted. In the transfer of knowledge about the traditional way of the Kazakhs, an important role belongs to the folklore and ethnographic ensemble of grandmothers and daughtersin-law "Kogaly-AI" (translated from Kazakh as "cane"), where the head of Suramysova Suksyr not only teaches the basics of ethnographic art, but also the competence of the basics of behavior of Kazakh girls.

Modern school is focused on the implementation of the activity approach, therefore, in our opinion, it is advisable to see in the teaching methods what creates a joint activity of the teacher and students in the classroom, aimed at achieving modern educational results. The democratization of society has created opportunities for innovative renewal of education as a source of new potentials for social renewal. Innovative processes have revealed the need to educate a flexible, dynamic person who wants to live in new, constantly changing conditions. One of the main provisions in the personality-oriented approach to learning is the focus on the development of the student's personality as an active subject of educational activity and comprehensive preparation for the continuous process of education, self-development and selfimprovement throughout life. Based on these principles, in the author's school for high school students were organized training courses working specialties as "master seamstress" (head: master teacher A. Abdurakhmanova); "car Driver category "C", "car Mechanic "(head: instructor Kolomeitsev V. M.); "Assistant driller" (head: engineer-geologist B. Serikbayev).
Thus, the personality of the teacher in a rural school plays a crucial role. At the same time, the peculiarity of the traditional Kazakh way of life, preserved in rural areas, allows to attract the local population to the educational process by organizing optional activities and intra-school organizations of interest.

\section{REFERENCES}

1. Gorokhova, Y. V. (2015). The Role of the Teacher in the Modern School// Pedagogical Skills: Materials VII International. Science. Conf. (Moscow, November 2015). - Moscow: Buki-Vedi, 8-10. URL

Https://Moluch.Ru/Conf/Ped/Archive/184/9055/ (Accessed 16.10.2019) (In Russian).

2. Hasanova P. M. (2015). The Role Of Teachers In Modern Society // Proceedings Of The VII International Student Scientific Conference "Student Scientific Forum" URL: <A Href="Https://Scienceforum.Ru/2015/Article/2015 013557">Https://Scienceforum.Ru/2015/Article/20 15013557</A> (Accessed 16.10.2019).

3. Stukalenko, N. M. (2018). Research of Ethnopedagogical Approach in Professional Training of Teachers. International Journal of Applied and Fundamental Research, 6.

4. Rahmi, R., Fitriati, F., \& Fachraini, S. (2019). An Analysis of Teachers' Perceptions toward the Role of ICT Based Media in Teaching and Learning Process among Primary Schools' Teachers. Jurnal Ilmiah Peuradeun, 7(3), 469-482. Available At: <Https://Journal.Scadindependent.Org/Index.Php/Ji peuradeun/Article/View/335>. Date Accessed: 30 Oct. 2019.

5. Selasih, N. N., \& Sudarsana, I. K. (2018). Education Based on Ethnopedagogy in Maintaining and Conserving the Local Wisdom: A Literature Study. Jurnal Ilmiah Peuradeun,6(2), 293-306. Available At: $<$ Https://Journal.Scadindependent.Org/Index.Php/Ji peuradeun/Article/View/219>. Date Accessed: 30 Oct. 2019. 